\title{
Viscosity of Himalayan leucogranites: Implications for mechanisms of granitic magma ascent
}

\author{
Bruno Scaillet, Francois Holtz, Michel Pichavant, and Michael Schmidt
}

Centre de Recherche sur la Synthèse et la Chimie des Minéraux

Centre National de la Recherche Scientifique, Orléans, France

\begin{abstract}
The viscosity of the Gangotri Himalayan leucogranite has been experimentally determined between 801$)^{\circ}$ and $1100^{\circ} \mathrm{C}, 300$ and $800 \mathrm{MPa}$, for meltwater contents of 3.98 and 6.66 wt \%. The melt viscosity is independent of pressure and shows an Arrhenian behavior relative to mperature within the range of conditions investigated. We present an empirical relation that can be used to determine leucogranite magma viscosities knowing their meltwater content and temperature. This relation together with phase equilibria experiments constrain the viscosity of the Himalayan leucogranites to be around $104.5 \mathrm{~Pa}$ s during their emplacement. These viscosities and the widths of dikes belonging to the feeder system are consistent with the theoretical relationship relating these two paraneters and show that the precursor magma of the leucogranite was at near liquidus conditions when emplaced within host rocks with preintrusion temperatures around $350^{\circ} \mathrm{C}$. Calculated terminal ascint rates for the magma in the dikes are around $1 \mathrm{~m} / \mathrm{s}$. Magma chamber assembly time is, on this basis, estimated to be less than 100 years (for a volume of $150 \mathbf{k m}^{3}$ ). In addition, the dynamical regime of the magma flow in the dikes was essentially laminar, thus allowing preservation ot any chemical heterogeneity acquired in the source. These results constrain the viscosity of melts formed during the first steps of crustal anatexis, those involving muscovite breakdown, to be also around $104.5 \mathrm{~Pa}$ s. Thus compaction may not be the only mechanism of melt segregation in part ially melted crustal rocks in view of the very short timescale inferred for magma ascent and emplacement.
\end{abstract}

\section{Introduction}

The diking mechanism is the widely accepted mode of magma transport for basaltic magmas, as testified by abundant field evidence of basaltic dikes [e.g., Wada, 1994]. In contrast, the common circular plan view of many granitic intrusions is perhaps the argument that has convinced many authors that diapiric uprise is a viable mechanism of transfer for granitic magmas [e.g., Pons et al., 1995] (see also reviews by Paterson and Fowler [1993], Paterson et al. [1991], Brown et al. [1995]). This mode of ascent went virtually uncontested for decades until Clemens and Mawer [1992] proposed, on thermal and mechanical grounds, that diking was a more viable alternative than diapirism for felsic melt migration [see also Petford et al, 1993]. A major criticism of the diapir model is that rates of magma ascent, as obtained from early thermal and mechanical modeling [e.g., Mahon et al., 1988], are extremely low, which should allow for extensive heat loss toward country rocks and thus crystallization at depth, while a number of geologic arguments show that granite intrusions are clearly disconnected from their source zone [Miller et al., 1988]. However, Weinberg and Podlachikov [1994] have shown that rates of diapiric rise can significantly increase (e.g., $100 \mathrm{~m} / \mathrm{yr}$ ) if the crust behaves in a non-Newtonian fashion. Similarly,

Copyright 1996 by the American Geophysical Union.

Paper number 96JB01631.

$0148-0227 / 96 / 96 \mathrm{JB}-01631 \$ 09.00$ the recent mathematical analysis of $R u$ bin [1995] suggests that the thermal viability of granitic dikes should prevent them from propagating far from the source region, thus showing that the diking model has its shortcoming too. Clearly, the question of whether granite ascent through the crust occurs only via dukes or only via diapiric rise is not likely to be resolved through theoretical analysis alone, inasmuch as both the diapir and dike mechanisms need not to be exclusive to each other [Rubin, 1993].

Although the case for granitic dikes is clear by the analyses of Clemens and Mawer [1992] and Pefford et al. [1993], assessment of this mechanism of ascent for natural felsic magmas has been, as yet, seriously hampered by two factors. The first is that in marsed contrast to basaltic dikes, wellidentified examples of teeder dikes of plutonic systems are exceedingly rare [e.g., Le Fort, 1981; John, 1988; Scaillet et al., 1995a], a direct consequence of the fact that the bottom contact of most plutonic intrusions is not visible. The second is that the determination of the viscosities of magma frozen in dikes is, for obvious rcasons, not straigthforward. Current attempts [e.g., Petford et al., 1993; Wada, 1994] rely on the empirical model of Shan [1972] which requires knowledge of the melt composition, including its water content, melt temperature, and amount of crystals present at the time of dike intrusion. These parameiers (in particular, the water content which most of the time is fixed arbitrarily) are poorly known for most plutonic rocks. The lack of precise determination of magma viscosity, a mastir variable that may influence whether granitic magmas will ascend as a diapir or as a dike [e.g., Emerman and Marret, 1990; Rubin, 1993], is a weakness in the present status of the diking model that has obscured the 
relationship between dike width and viscosity, particularly for felsic magmas [Petford et al., 1993].

In this study, we use an exceptional geological area where melt migration undoubterlly occurred via diking, as seen in the field, and ultimately filled batholithic sized bodies, to examine theoretical models for magma ascent via diking as applied to granitic magmas. The region of interest is the High Himalaya range where highly dissected relief provides natural cross sections of great vertical extent enabling accurate three dimensional representation of the plutonic bodies [e.g., Scaillet et al., 1995a]. These are the High Himalayan Leucogranites (HHL) which have been extensively studied in the recent years and whose petrogenesis is well known [e.g-, Le Fort et al., 1987; Castelli and Lombardo, 1988; Inger and Harris, 1993]. In particular, important parameters that control magma rbeology such as temperature, weight percent $\mathrm{H}_{2} \mathrm{O}$ in melt, crystallinity, and nuelt composition of the magma at the time of its emplacement in the higher levels of the crust are now well constrained by experimental data [Scaillet et al., 1995b]. Rather than using the empirical model of Shaw [1972] we have experimentally determined the melt viscosity of a High Himalayan leucogranite within $\mathrm{P}, \mathrm{T}$, weight percent $\mathrm{H}_{2} \mathrm{O}$ conditions relevant to its entire petrogenetic history (as inferred from phase equilibrium and petrographic studies). These viscosity measurements combined with the field data provide the first comparison of the theoretical relationship relating dike width to the magma viscosity [Petford et al., 1993]. We show below that such a relation is entirely consistent with the emplacement of the HHL as near liquidus magmas and that the emolacement time required for complete assembly of the laccolitt was only a few years in upper crust whose temperature was around $350^{\circ} \mathrm{C}$.

\section{The Himalayan Leucogranite Laccoliths}

The HHL were produced during the collision between the Indian subcontinent and Eurasia which started circa $65 \mathrm{Ma}$ [Beck et al., 1995]. Geological mapping carried out over the past 30 years has shown that these leucogranites form discrete bodies cropping out regularly all along the $2000 \mathrm{~km}$ of extent of the Himalayan range: Each body has invariably a lens shape, being emplaced most of the time within metasedimentary rocks with clear intrusive contacts [e.g., Castelli and Lombardo, 1988; France-Lanord and Le Fort, 1988; Searle et al., 1993; Inger and Harris, 1993; Scaillet et al., 1995a]. In this report we will focus on the Garhwal Himalaya, where both the granite and its feeder system are exposed in the Gangotri region along vertical cliffs of more than $2500 \mathrm{~m}$ of relief. Detailed structural studies of this area have shown that magnia emplacement took place during extensional tectonism in the Himalayan orogen contemporaneously with, or subsequent to, the crustal thicknening process [Searle et al., 1993; Scaillet et al., 1995a]. The feeder system is made up of hundreds of dikes whose vertical extension is at least $1000 \mathrm{~m}$, with thicknesses varying between 10 and $50 \mathrm{~m}$, most of them intersecting the bottom contact of the laccolith (Figure 1). This general disposition led Scaillet et al. [1995a] to propose that the intrusive bodies represeat genuine laccoliths, having grown by lifting up the overlyng metasediment. The heterogeneity in $\mathrm{Rb} / \mathrm{Sr}$ isotopes suggests that the whole body corresponds to the assembly of different magmas batches which did not undergo any subsequent vigorous mixing process [e.g., Deniel et al., 1987]. Owing to the general lack of intrusive contacts within the laccolith (j.e., between the different magma batches), the growing time of each individual laccolith must have been extremely short in order to prevent any significant cooling of each individual unit during the growth of the laccolith. Preliminary numerical thermal modeling shows that a 2-km-thick laccolith should cool below its solidus within 30,000 to 100,000 years. depending on the thermal regime of the crust and on the thermal diffusivity value chosen for the magma (B. Scaillet, manuscript in preparation, 1996). These calculations provide an upper bound for the assembly time of the laccoliths at the level of emplacement Petrographic and experimental studies [Scaillet et al., 1995b] have shown that these magmas were emplaced as crystal-poor melts ( $<5$ vol \%), at temperatures ranging from $800^{\circ}$ to $750^{\circ} \mathrm{C}$ (biotite-muscovite facies) to $750^{\circ}$ to $700^{\circ} \mathrm{C}$ : (tourmaline-muscovite facies), with melt water contents varying between 5.5-7 (Bt-Ms) and >7 (Tur-Ms) wt \% $\mathrm{H}_{2} \mathrm{O}$. The pressure of emplacement is constrained to have been between 300 and $400 \mathrm{MPa}$, on the basis of thermobarometric results obtained on associated thermal aureoles [Guillot et al., 1993], while the pressure of magma generation was between 700 and $1000 \mathrm{MPa}$ [e.g. Pêcher, 1989]. Thus the magma underwent a pressure drop of around 300-400 MPa during emplacement.

\section{Experimental Determination of Leucogranite Viscosities}

\section{Experimental Method}

The experimental method used to determine the viscosity of hydrous melts is the falling sphere technique. In this study the same procedure as that used by Schulze et al. [1996] was followed, and the reader is referred to that work for full technical details. Only the salient features will be repeated here. A hydrous glass cylinder was prepared by melting the rock powder (natural tourmaline-muscovite bearing leucogranite GB4 of Scaillet et al. [1995b]) loaded within a Pt capsule together with an appropriate amount of distilled and deionized water. The melting was done at $300-400 \mathrm{MPa}$, at $1100^{\circ}-1200^{\circ} \mathrm{C}$ for $3-4$ days to ensure a homogeneous distribution of water. A glass cylinder free of bubbles approximately $4 \mathrm{~cm}$ long and $0.5 \mathrm{~cm}$ in diameter was obtained. The cylinder was sawed across so as to obtain a long $(2-3 \mathrm{~cm})$ and a short $(0.5 \mathrm{~cm})$ cylinder. The two cylinders were subsequently stuck together within a new Pt capsule (diameter $0.4 \mathrm{~cm}$ ), with $\mathrm{Pt}$ powder in between. This Pt surface (thickness 1-2 $\mu \mathrm{m}$ ) was used as a reference level to measure the position of the Pt spheres before and after the experiment. On the other end of the cylinder, a small layer of glass powder, obtained from crushed fragments of the same glass cylinder, was added. Two Pt spheres were placed within the powdered glass. The Pt capsule was finally welded shut and brought to the desired P-T conditions. After an experiment under a given set of P-T conditions, the next one was performed by using the same glass cylinder simply turned upside down to allow the spheres to settle back in the opposite direction. This procedure allowed us to use the same glass :ylinder (with the same water content) for various $P$ and $T$ conditions (up to 10 experiments were with the same cylinder). The water content of the glass cylinder was measured by Karl Fischer titration (KFT) betore and/or after (on both ends of the glass cylinder) a given set of 

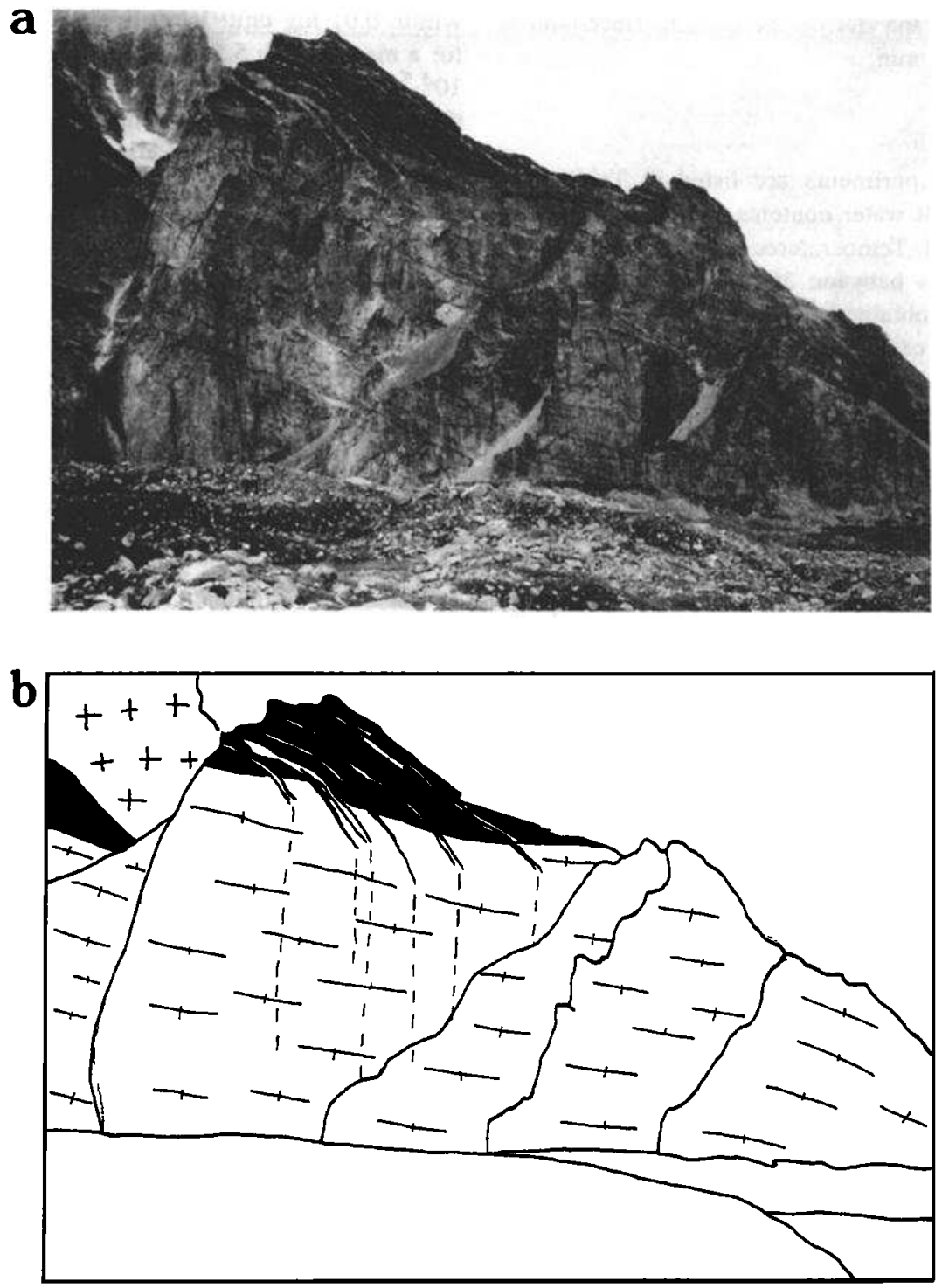

Figure 1. (a) Photograpb of the south face of the Shivling peak showing the base of a leucogranite laccolith with the array of feeder dikes that still connect to the bottom of the intrusion. The height of the cliff is about $1300 \mathrm{~m}$. The leucogranite is intruded into black schist that overlies a thick layer of orthogneisses. In the latter, the dikes are nearly vertical, while they are tilted in the schist as a consequence of the late orogenic extensional collapse [see Scaillet et al., 1995a]. (b) Schematic line drawing of the Figure 1a enhancing the geological contours of the main units. Only the upper reaches of the thicker dikes are drawn, when they cross the black schist level: crosses, leucogranite; horizontal crosses, orthogneisses. The intermediate level of schist is black.

experiments and was determined to be constant, within the analytical uncertainty of the KFT technique (0.3 wt \% $\left.\mathrm{H}_{2} \mathrm{O}\right)$. The falling distances of the Pt spheres were measured with an optical microscope equipped with an automated X-Y-stage enabling measurements to be performed with a precision of $0.001 \mathrm{~cm}$. Given the fact that two $\mathrm{Pt}$ spheres were used, each experiment gave two independent measurements of the viscosity. The viscosity was calculated from Stokes' law, crrected for border effects (Faxen correction), using the run duration, the radius of the Pt sphere (determined to $\pm 5 \mu \mathrm{m}$ by optical and weighting methods) and the densities of the $\mathrm{Pt}$ sphere $\left(21,450 \mathrm{~kg} / \mathrm{m}^{3}\right)$ and melts. In our experiments, cabculated melt densities vary between $2290 \mathrm{~kg} / \mathrm{m}^{3}$ at $800^{\circ} \mathrm{C}$ ad $6.66 \mathrm{wt} \% \mathrm{H}_{2} \mathrm{O}$ and $2310 \mathrm{~kg} / \mathrm{m}^{3}$ at $1100^{\circ} \mathrm{C}$ and $3.98 \mathrm{wt} \%$
$\mathrm{H}_{2} \mathrm{O}$. For a fixed meltwater content and temperature this difference in melt density produces a variation of $2.5 \times 10^{-4} \mathrm{log}$ unit on the calculated viscosity. Therefore for convenience, a constant melt density of $2300 \mathrm{~kg} / \mathrm{m}^{3}$ was used in all viscosity determinations. All experiments were performed within an internally heated pressure vessel, pressurized with argon and working vertically. Total pressure is known within 50 bars. The temperature was read by at least three PtRh30 thermocouples and is kr.own to within $\pm 10^{\circ} \mathrm{C}$ (including the gradient across the capsule [see Roux et al., 1994]). The length of the glass cylinders allowed us to perform runs of long duration, between about 3 and 78 hours, with settling distances ranging from 0.2 to $1 \mathrm{~cm}$, which virtually eliminates any error arising from the settling of $\mathrm{Pt}$ spheres prior to attainment of 
experimental conditions and during the quench. Uncertainties for settling times are $\pm 5 \mathrm{~min}$.

\section{Results}

The results of 11 experiments are listed in Table 1 in chronological order. Melt water contents of 6.66 and $3.98 \mathrm{wt}$ $\%$ have been investigated. Temperatures ranged from $800^{\circ} \mathrm{C}$ up to $1100^{\circ} \mathrm{C}$ and pressure; between 300 and $800 \mathrm{MPa}$. In all experiments, viscosities obtained from the two Pt spheres are within $0.02 \mathrm{log}$ unit of each other. Replicate experiments at around $860^{\circ} \mathrm{C}$ give viscosities that agree within $0.05 \mathrm{log}$ units. Overall, the uncertainty in viscosity measurements is estimated to be better than $0.05 \mathrm{log}$ units. Experiments performed at $860^{\circ} \mathrm{C}$ and 500 and $800 \mathrm{MPa}$ with a meltwater content of 6.66 wt $\% \mathrm{H}_{2} \mathrm{O}$ yield viscosities that are identical within error (Table 1), indicating that pressure has no detectable effect on hydrous melt viscosities within this range of pressure variation, as shown also by Burnham [1964] and Schulze et al. [1996]. The two sets of experiments display linear behavior in an Arrhenius plot (Figure 2), with correlation coefficients close to $1\left(0.999\right.$ for $3.98 \mathrm{wt} \% \mathrm{H}_{2} \mathrm{O}$ and 0.993 for $6.66 \mathrm{wt} \% \mathrm{H}_{2} \mathrm{O}$ ). The activation energy of viscous flow decreases slighty with increasing water content, as observed in the haplogranite system [Schulze et al., 1996]. All the experimental data have been fit with the following equation:

$\log \eta=16280 / T-7.5461+[0.59784$

$$
-1235.4 / T] \text { wt } \% \mathrm{H}_{2} \mathrm{O}
$$

where $\eta$ is the viscosity in pascal seconds, $T$ is the temperature in kelvins and weight percent $\mathrm{H}_{2} \mathrm{O}$ is the water content of the melt. This equation reproduces the experimental viscosities

Table 1. Experimental Viscosities of Leucogranite Melts

\begin{tabular}{|c|c|c|c|c|c|}
\hline Run & $\begin{array}{c}\mathrm{P}, \\
\mathrm{MPa}\end{array}$ & $\begin{array}{l}\mathrm{T}, \\
{ }^{\circ} \mathrm{C}\end{array}$ & $\begin{array}{c}\text { duration, } \\
\mathbf{s}\end{array}$ & $\begin{array}{c}\log \eta_{1} \\
\mathrm{Pas}_{\mathrm{s}}\end{array}$ & $\begin{array}{c}\log \eta_{2}, \\
\mathrm{Pas}\end{array}$ \\
\hline
\end{tabular}

\begin{tabular}{lccccc}
\hline \multicolumn{5}{c}{6.66 ut $\% \mathrm{H}_{2} \mathrm{O}$ in Melt } \\
4 & 500 & 860 & 63420 & 3.58 & 3.57 \\
5 & 500 & 910 & 18660 & 3.25 & 3.22 \\
6 & 500 & 855 & 46860 & 3.55 & 3.53 \\
7 & 500 & 800 & 72000 & 3.94 & 3.93 \\
8 & 500 & 865 & 28680 & 3.54 & 3.54 \\
9 & 800 & 860 & 45900 & 3.52 & 3.51 \\
10 & 500 & 955 & 9000 & 3.00 & 2.99 \\
11 & 650 & 813 & 75300 & 3.86 & 3.86 \\
& \multicolumn{5}{c}{} \\
& & 3.98 wt $\% \mathrm{H}_{2} \mathrm{O}$ in Melt $\$$ & \\
12 & 300 & 1100 & 14880 & 3.09 & 3.10 \\
13 & 300 & 1001 & 35770 & 3.79 & 3.77 \\
14 & 300 & 907 & 280300 & 4.45 & 4.45 \\
& \multicolumn{5}{c}{} \\
\hline
\end{tabular}

$P$, pressure; $T$, temperature.

${ }^{*} \mathrm{Pt}$ spheres of radius $0.0110 \mathrm{~cm}$ and $0.0127 \mathrm{~cm}$. $\S \mathrm{Pt}$ spheres of radius $0.0132 \mathrm{~cm}$ and $0.0136 \mathrm{~cm}$. within $0.01 \log$ unit. It predicts a viscosity of $10^{4.6}-10^{5} \mathrm{Pas}$ for a magma with $5.5 \mathrm{wt} \% \mathrm{H} 2 \mathrm{O}$ at $800^{\circ}-750^{\circ} \mathrm{C}$ and of $10^{4} .1$ $10^{4.5} \mathrm{~Pa} s$ for a magma with $7 \mathrm{wt} \% \mathrm{H}_{2} \mathrm{O}$ at $750^{\circ}-700^{\circ} \mathrm{C}$. (Note that the Arrhenian approximation is strictly valid only for small temperature ranges. Use of equation (1) well outside experimental range of calibration may give erroneous results.) These conditions correspond to those during the emplacemes. of biotite-muscovite and tourmaline-muscovite beariar leucogranites, respectively, as inferred from phase equilibriam experiments [Scaillet et al., 1995b]. However, given the narrow range of these viscosity determinations and for the sake of simplicity, in the following section we will consider average values of $750^{\circ} \mathrm{C}$ for the temperature of emplacemes and $10^{4.5} \mathrm{~Pa}$ s for the magma viscosity.

\section{Implications for the Diking Mechanism}

The results obtained in this study provide direct constraints on the relationships existing between dike width and magna viscosity. Dike width is an easily measured parameter in the field [e.g. Wada, 1994], and it has long been recognized, least qualitatively, that the less viscous the magma the narrower the dike. Petford et al. [1993, 1994] used the mathematical analysis of Bruce and Huppert [1989, 1990] to derive a relation between dike width and magma viscosity:

$$
w_{c}=1.5\left[c\left(T_{\mathrm{sol}}-T_{\mathrm{w}}\right)^{2} / L\left(T_{\mathrm{liq}}-T_{\mathrm{so}}\right)\right]^{3 / 4}(\eta k H / g \Delta \rho)^{1 / 4}
$$

where $w_{C}$ is the critical dike width necessary to prevent is thermal lock-up during melt flow, $T_{\text {liq }}$ is the magma initial temperature $\left(750^{\circ} \mathrm{C}\right)$, and $T_{\text {sol }}$ is the temperature at which the magma near the dike wall becomes immobile, here taken to be that of the solidus $\left(645^{\circ} \mathrm{C}\right)$. Strictly, the temperature at which magma stop flowing differs from that of the solidus bat leucogranite magmas have a strong eutectic-like behavior [Scaillet et al., 1996], being $80 \%$ liquid $15^{\circ} \mathrm{C}$ above the solidus, and this difference should not exceed $10^{\circ} \mathrm{C}$. The specific heat, $c\left(1600 \mathrm{~J} / \mathrm{kg}{ }^{\circ} \mathrm{C}\right)$, was calculated using the bull composition and the model of Lange and Navrotsity [1992] for all oxides except for water whose partial molar specific beat was taken from Clemens and Navrotsky [1986]. The density difference between the magma and the host rack, $\Delta p$, was calculated with an averaged weighted mean density of 2700 $\mathrm{kg} / \mathrm{m}^{3}$ for the country rocks [e.g., Corry, 1988] and a melt density calculated using the bulk composition and partial molar volumes of Knoche et al. [1995] for all oxide components except for $\mathrm{FeO}$ and $\mathrm{H}_{2} \mathrm{O}$ whose partial molar volumes were taken from Lange and Carmichael [1990] and Holtz et al. [1995], respectively. The thermal diffusivity $k$ was set to $8 \times 10^{-7} \mathrm{~m}^{2} / \mathrm{s}$, and $g$, the gravitational constant, was set to $10 \mathrm{~m} / \mathrm{s}^{2}$. All the previous input parameters of (2) can be considered as well constrained. In contrast, $T_{w}$, the far-fiets wall rock temperature, $L$. the latent heat of crystallization, $H$, the dike length, are more difficult to assess. A miniming value for $H$ is the present vertical extent of dikes $(1000 \mathrm{~m})$, while a maximum value is given by the difference between the depth of magma generation, which is estimated to be between 7 and $10 \mathrm{kbar}$, and its level of emplacement. Varying $H$ between 1000 and $20,000 \mathrm{~m}$, keeping all other values constant (with $L=3 \times 10^{5} \mathrm{~J} / \mathrm{kg}$ and $T_{w}=300^{\circ} \mathrm{C}$, see next section) increases the critical dike width from about 1 to $2 \mathrm{~m}$, which shows that this parameter has little influence on the estimate of $w_{c}$. Although reasonable, these thicknesses are -1 order ef 


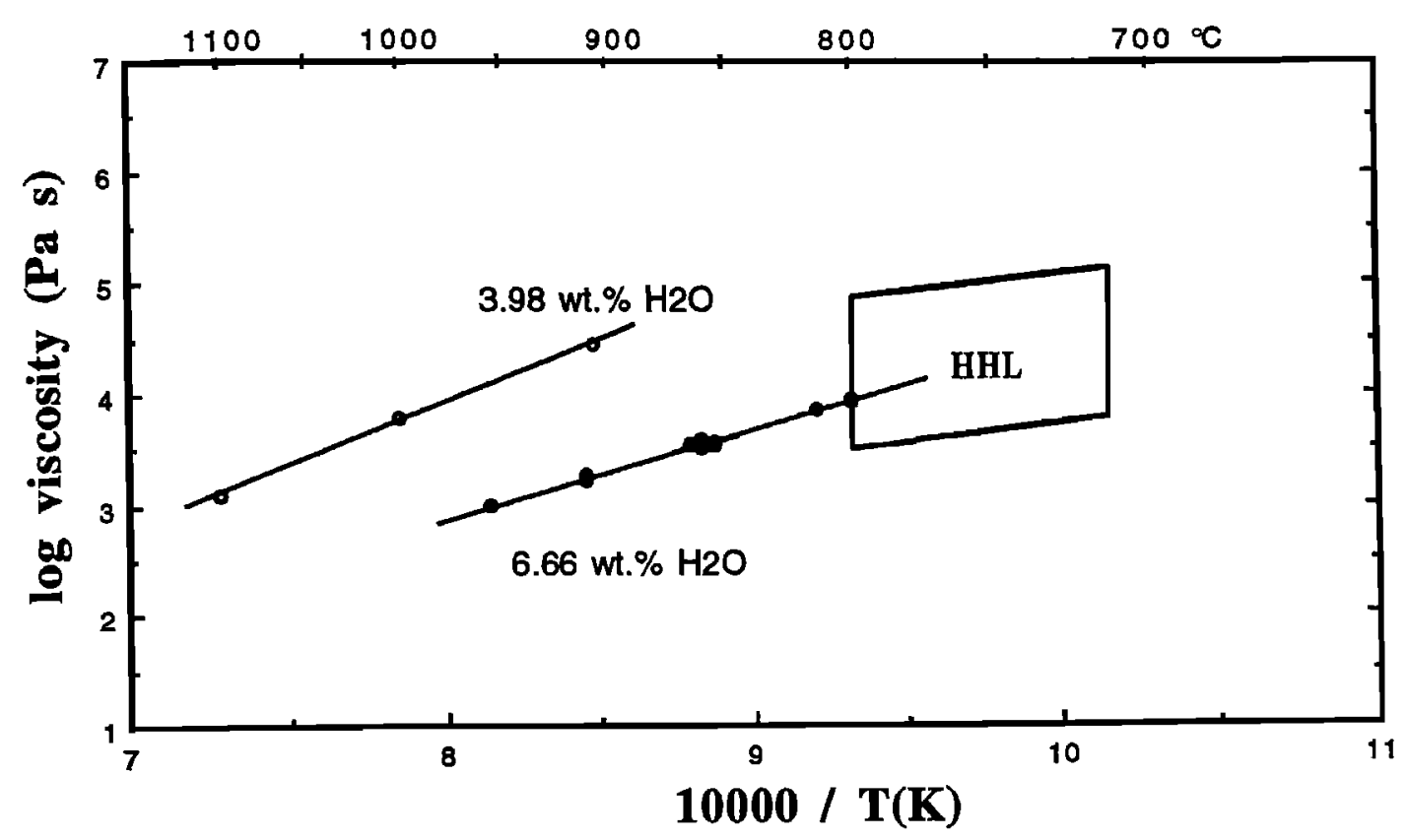

Figure 2. Arrhenius plot of experimental viscosities determined for a High Himalayan leucogranite at two meltwater contents. The box indicates the range of magma viscosities during the emplacement of Himalayan leucogranites, as inferred from phase equilibria and petrographical studies [Scaillet et al., 1990, 1995b] and from the present work.

magnitude lower than those observed (10-20 $\mathrm{m}$, or even more). However, this first calculation is based on the premise that the latent heat is being released uniformly across the crystallization interval. In fact, crystallization paths obtained from phase equilibrium diagrams show that such leucogranites are still $70-80 \mathrm{wt} \%$ liquid $15^{\circ} \mathrm{C}$ above their solidus [Scaillet et al., 1996]. In other words, the contribution of latent heat to the heat budget of the magma during its crystallization is highly non linear, being minimal at near-liquidus conditions, and a value of $3 \times 10^{5} \mathrm{~J} / \mathrm{kg}$ greatly overestimates the amount of heat released by crystallization during dike intrusion. The effect of latent heat on the critical dike width is illustrated on Figure 3 for a magma having a viscosity of $10^{4.5} \mathrm{~Pa} s$ at $750^{\circ} \mathrm{C}$ emplaced in a host rock at $300^{\circ} \mathrm{C}$. Also shown is the approximate amount of accumulated heat released by the crystallization of a leucogranite magma between $750^{\circ}$ and

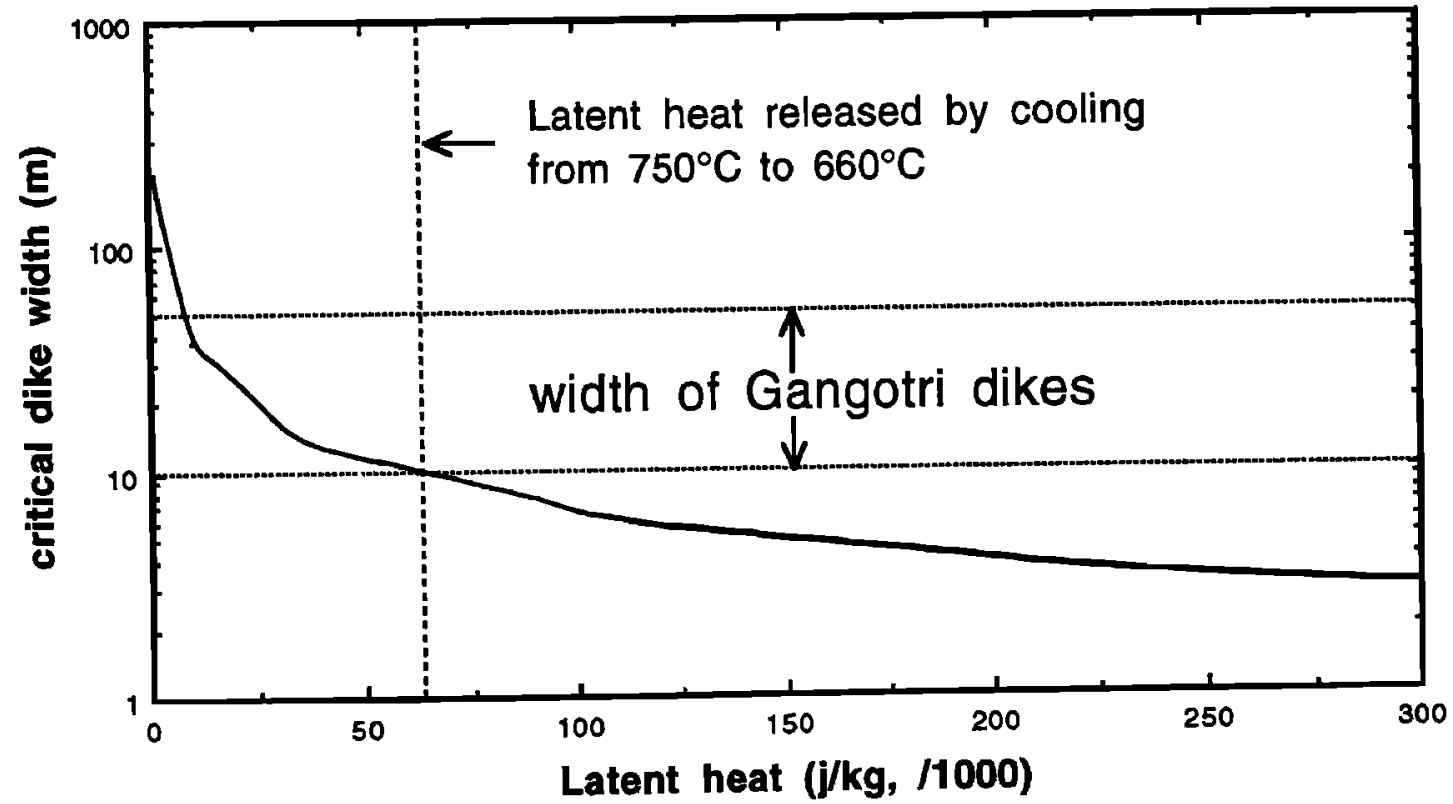

Figure 3. Effect of latent heat of crystallization on the critical dike width for a leucogranite magma at $750^{\circ} \mathrm{C}$ with a viscosity of $10^{4.5} \mathrm{~Pa}$ s. Also shown is the range of widths for the Gangotri dikes that are clearly connected to the base of the laccolith (Figure 1). The approximate amount of cumulated latent heat released during the crystallization of a leucogranite magma betweem $750^{\circ}$ and $660^{\circ} \mathrm{C}$ is reported. 
$660^{\circ} \mathrm{C}$, as estimated from phase equilibrium experiments [Scaillet et al., 1995b]. Clearly, the preserved dike thicknesses indicate that the amount of latent heat released during dike intrusion was small, probably below $1 \times 10^{5} \mathrm{~J} / \mathrm{kg}$. The dike thicknesses are thus consistent with a magma emplacement at near-liquidus conditions, as shown by petrographic and experimental studies [Scaillet et al., 1990, 1995b; Inger and Harris, 1993]. They also fit with the overall trend established by Wada [1994] between dike thickness and magma viscosity, falling midway (10-50 m, 104-5 $\mathrm{Pa} \mathrm{s}$ ) between those reported for mafic $\left(1 \mathrm{~m}, 10^{1}-10^{2} \mathrm{~Pa} \mathrm{~s}\right)$ and viscous felsic $\left(100 \mathrm{~m}, 10^{6}-10^{7} \mathrm{~Pa} \mathrm{~s}\right)$ magmas. The combined use of experimental and field data supports the theoretical approach followed by Petford et al. [1993, 1994] and shows that, in this particular case, dike width is a precise indicator of magma viscosity, provided that other controlling factors such as the latent heat budget during crystallization or the host rock temperature (see below) are also well constrained.

\section{Implications for Magma Emplacement Time}

The minimum time required to assemble the magma chamber can be obtained by using the equation of fluid flow in a tabular conduit that approximates the dike geometry. The general form of this equation is [e.g., Petford et al., 1994]

$$
V_{\mathrm{a} \text { ve }}=g \Delta \rho w^{2} / 12 \eta
$$

where $\mathrm{V}_{\mathrm{ave}}$ is the average velocity of magma flow and $w$ is the dike width. Taking a minimum value of $10 \mathrm{~m}$ for the dike width, the flow velocity varies between $2.6 \mathrm{~m} / \mathrm{s}$ and $0.3 \mathrm{~m} / \mathrm{s}$ for a magma with a viscosity $\eta$ of 104.1 and $10^{5.01} \mathrm{~Pa} \mathrm{~s}$, respectively. The hori:zontal length of the dikes is not precisely known but should be no more than a few hundred meters. A single dike with $300 \mathrm{~m}$ of horizontal extension could therefore fill a $150 \mathrm{~km}^{3}$ magma chamber (the maximum volume of a laccolith in the Gangotri area) in less than 2 years.
As there are probably more than a hundred dikes, the time of chamber building can be considered as instantaneous if all dikes were active together. Thus the 2-km laccolith assembly time should lie between 1 and 100,000 years, the maximum cooling time to attain solidus conditions as obtained from numerical simulations (B. Scaillet, manuscript in preparation, 1996). However, a time at the lower end of this range is presently favored because of the near constancy of dike widths, as preserved now in the field. In fact, equation (2) predicts that the critical dike width will decrease with increasing bost roct temperature. This is what is shown on Figure 4, where the relation between critical dike width and host rock temperature is shown for a magma at $750^{\circ} \mathrm{C}$ and for different values of latent heat. The widths of the Gangotri dikes are reproduced at host rock temperatures below $400^{\circ} \mathrm{C}$, with the most reasonable preintrusion temperatures being located at around $350^{\circ} \mathrm{C}$. Had the process of magma incoming been protracted (e.g., bundreds of thousands (ff years), then the host rocks would have had time to warm up, which should bave significantly decreased the width of the latest dikes intruded. For instance, with a value of $T_{w}=600^{\circ} \mathrm{C}$ the critical dike width drops to around $0.5 \mathrm{~m}$ (i.e., almost 2 orders of magnitude below observed thicknesses). Significantly, a temperature around $350^{\circ} \mathrm{C}$ is that expected at a depth of $15 \mathrm{~km}$ in a continental crust having a normal geothermal gradient. If the preintrusion temperature was $500^{\circ} \mathrm{C}$ at $15 \mathrm{~km}$ depth, then temperatures of around $1000^{\circ} \mathrm{C}$ would prevail at $30 \mathrm{~km}$ of burial, conflicting with existing thermal models of thickened continental crust [e.g., England et al., 1992], which show that even when the thermal relaxation process is completed (i.e., $-60 \mathrm{Myr}$ after the stacking of the crust), temperatures at such depths (in the hanging wall of the thru it sequence) hardly exceed $700^{\circ} \mathrm{C}$. In addition, numerical simulations of magma cooling (B. Scaillet, manuscript in preparation, 1996) reproduce the observed metamorphic peak temperatures of around $550^{\circ} \mathrm{C}$ in the contact aureole only for preintrusion temperatures below $400^{\circ} \mathrm{C}$. Temperatures in excess of this value yield much higher metamorphic grades in the aureole, in some cases reaching

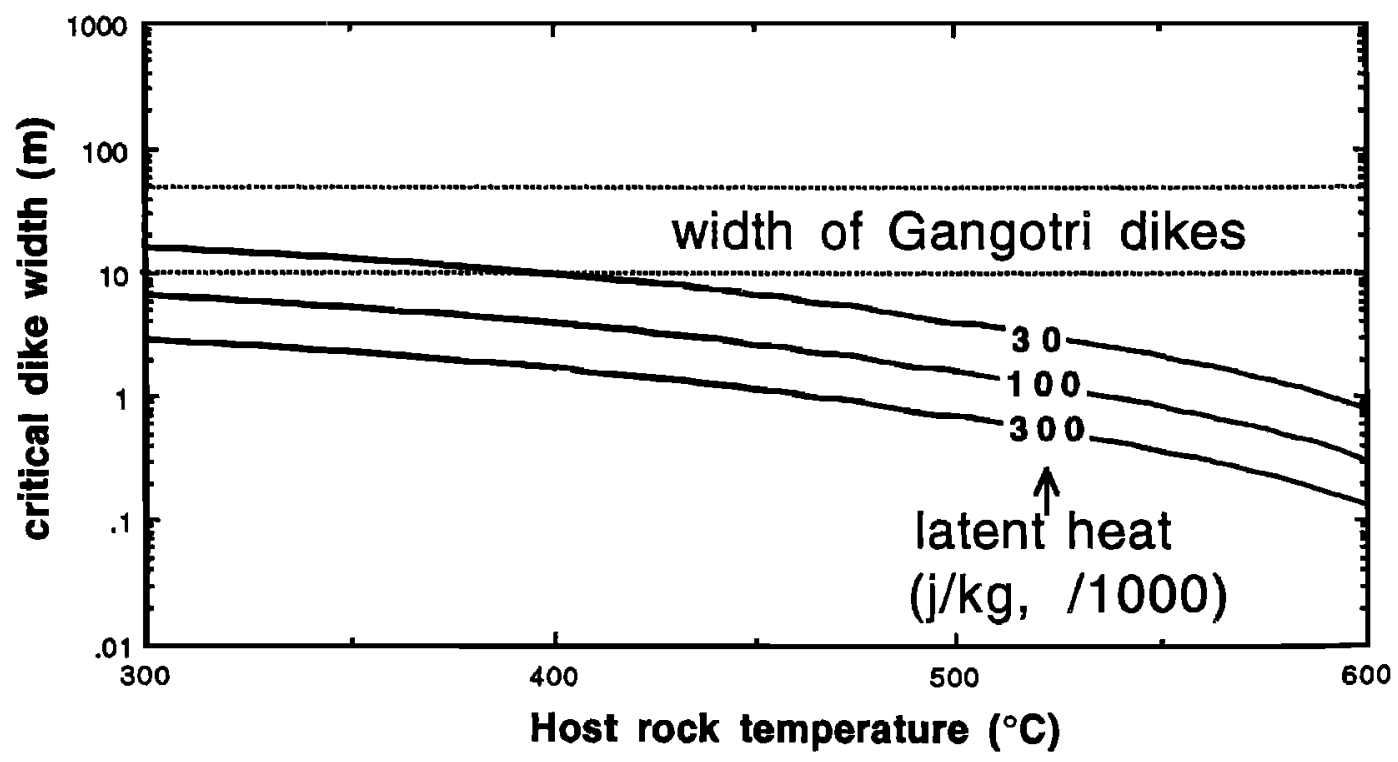

Figure 4. Effect of host rock temperature on the critical dike width for a leucogranite magma at $750^{\circ} \mathrm{C}$, with a viscosity of $10^{4.5} \mathrm{~Pa} s$ and for three values of latent heat: $0.3 \times 10^{5}, 1 \times 10^{5}$, and $3 \times 10^{5} \mathrm{~J} / \mathrm{kg}$. Also shown is the range of widths for the Gangotri dikes that are clearly connected to the base of the laccolith (Figure 1). 
conditions of incipient partial melting $\left(>650^{\circ} \mathrm{C}\right.$ ). Such festures are lacking in the Gangotri region, and we therefore conclude that magma intrusion in this area took place in an aready cold upper crust [see also Copeland et al., 1990], the emplacement process being achieved in an extremely short period, a fact endemic to most laccolithic intrusions [Corry, 1988]. This cold environment is in agreement with the hypothesis of Scaillet el al. [1995a] of the magma fractures being arrested by collapse folds in the upper crust at a level close to the brittle to ductile transition [see also Hogan and Gilbert, 1995].

\section{Implications of High Rates of Magma Flow}

The rates of magma flow suggested by this study are among the highest ever calculated for silicic magmas. These high rates have two major implications. First, such rates of magma flow should minimize, or even impede, any chemical interaction with the country rocks encountered during uprise [Clemens and Mawer, 1992]. Thus the magma composition at its amival level is probably close to that produced by the melting reaction, just betore it left the source zone. It follows that these leucogranites can be possibly used as direct probes of the rheological properties of the melt in the melting source, owing to the lack of pressure dependence on melt viscosity. Thus it can be concluded that melt viscosity was around 104.5 $\mathrm{Pa} \mathrm{s}$ in the source area. The HHL are inferred to have been produced by a melting reaction involving the breakdown of muscovite with melt fractions in the source of about 10-15\% [eg., Le Fort et al., 1987; Harris and Inger, 1992]. The rate of melt segregation of a partially molten rock through a compaction mechanism can be evaluated with the physical model of McKenzie [1984]. Calculations done with a melt viscosity of $104.5 \mathrm{~Pa} s$ and a porosity of $10 \%$ give compaction times of the order of $10^{5}$ years [Wickham, 1987; Laporte, 1994]. Therefisre, in view of the extremely short timescales during which inagma ascent and emplacement occur, this result indicates that compaction alone is probably not an efficient process for melt segregation in the continental crust [see Wickham, 1987].

The second implication concerns the chemical heterogeneity (e.g., Sr isotopes) of leucogranitic magmas. The fluid dynamic regime of a magma flowing in a dike can be assessed through the Reynolds number which is defined as [e.g., Jaupart and Allegre, 1991]

$$
R e=\rho V_{\mathrm{ave}^{w} / \eta}
$$

Taking average values of $104.5 \mathrm{~Pa} \mathrm{~s}$ and $20 \mathrm{~m}$ for magma viscasity and dike width. respectively, the computed Reynolds aumber is 5 , which is well below the critical value of 2000 beyond which the onset of turbulent flow is predicted. Iscreasing the dike width up to the maximun observed in the field $(50 \mathrm{~m})$ and taking the lowest magma viscosity found in this study (104.1 $\mathrm{Pa}$ s) gives a Reynolds number of 603 . Therefore the dynamical regime of the magma flowing through the feeding system of the Gangotri laccolith can be predicted to be dominantly laminar. The lack of turbulence means that homogeneization of an heterogeneous batch of magma daring its uprise proceeds mainly through chemical diffusion. The very slow rate of cationic diffusion in silicate melts compared to the rate of magma ascent found in this study indicates that virtually any chemical heterogeneity inherited from the source will survive the ascent period. Therefore the chemical heterogeneity found at the outcrop scale does not necessarily imply the coexistence of different magma pulses having travelled in separate dikes, but it may also reflect the existence of a former single magma batch that was already heterogeneous in the source region. Besides the implications that such finding may have on the mechanisms and kinetics of partial melting processes occurring in the crust (i.e., equilibrium or disequilibrium melting, rate of melt extraction, see [Brown et al., 1995]) and which are beyond the scope of this paper, a first consequence is that it explains the existence of strong variations in somes isotopes (e.g., Sr) while physical boundaries testifying of the coexistence of several magma batches are lacking [Deniel et al., 1987].

\section{Concluding Remarks}

The High Himalayan leucogranites are a most spectacular example of the assembly of large granitic batholiths via diking on very short tinescales (i.e., of the order of years). This is not to say that every single granitic pluton or large batholith behaves in the way exemplified above. The HHL are derived from a crustal melting process alone with no mantle input [Le Fort et al., 1987]. In this respect they differ from most of the granites that belong to coastal batholiths such as the Sierra Nevada Batholith in California. In the latter, the mantle component represents a significant fraction, if not a dominant one, of the intrusive rocks. A consequence of this mantle involvement is that Cordilleran granites span a wider compositional range than do the HHL. This compositional diversity implies more complicated petrogenetic stories which in turn open the posisibility for having more complex rheological behaviors (i.e., different crystal/melt ratios during extraction, ascent and emplacement). Finally, it needs be stressed that the volume of magmatic material involved in these orogenic belts (from $20 \%$ up to $90 \%$, [Paterson and Fowler, 1993]) is much more important than that in the Himalayan range, where exposed plutons represent no more than $2 \%$ of this intracontinental belt [Le Fort et al., 1987]. A major consequence of this 1 order of magnitude of difference in the volume of intrusive rocks is the heat budget of the orogenic belt. Repeated injections of magmatic bodies over protracted periods associsted with large and sustained heat flux at the base of the crust may affect the rheological behavior of the medium through which granitic magmas ascend. In this context, first emplaced magmas may have emplacement mechanism(s) different(s) from latter ones [see Paterson and Fowler, 1993]. For instance, it can be envisaged that first injected magmas will traverse a cold crust through dikes, while latter ones will encouter a hotter medium, be it a heated crust or a fully or partially crystallized intrusion. In this case the viscosity contrast betu een the intruding magma and its hosting rocks may be more favourable (i.e., lower) to a diapiric rise. In comparison, the Gangotri leucogranites represent a short-lived magmatic event with limited thermal effects on the traversed terranes. At a larger scale the spacing between the different major plutons $(100-200 \mathrm{~km})$ belonging to HHL belt also precludes thermal interferences between them. Thus, in contrast with what probably occurs in magmatic arcs, the rheological properties of the crust were not significantly affected during the injection of the Gangotri magma (note that 
this may not be entirely true for the largest HHL plutons such as the Everest-Makalu or Manaslu granites). In summary, although the Gangotri leucogranites validate diking as a viable mode of ascent for siliciz magmas, they do not exclude other mechanisms of granite ascent and emplacement.

Acknowledgments. This study was financiated by grants from the IDYL research program of the CNRS. The first glass cylinder used to measure the viscosity was kindly prepared by Frank Schulze. An informal review done by Bernard Evans greatly improved the quality of the manuscript. The official reviews done by J.P. Hogan, D. Dingwell, and G. Bergantz are gratefully acknowledged.

\section{References}

Beck, R.P., et al., Stratigraphic evidence for an early collision between northwest India and Asia, Nature, 373, 55-58, 1995.

Brown, M., T. Rushmer, and E. W. Sawyer, Introduction to special section: Mechanisms and consequences of melt segregation from crustal protoliths, J. Geophys. Res., 100, 15551-15563, 1995.

Bruce, P.M., and H.E. Huppert, Thermal control of basaltic fissure eruptions, Nature, 342, 665-667, 1989.

Bruce, P.M., and H.E. Huppert, Solidification and melting along dykes by the laminar flow of basaltic magmas in Magma Transport and Storage, edited by M.P. Ryan, pp. 87-101, John Wiley, New York, 1990.

Burnham, C.W., Viscosity of a water rich pegmatite melt at high pressures, Spec. Pap. Geol. Soc. Am., 76, 26, 1964.

Castelli, D., and B. Lombardo, The Gophu La and western Lunana granites: Miocene muscovite leucogranites of the Bhutan Himalaya, Lithos, 21, 211-225, 1988.

Clemens, J.D., and C.K. Mawer, Granitic magma transport by fracture propagation, Tectonophysics, 204, 339-360, 1992.

Clemens, J.D., and A. Navrotsky, Mixing properties of $\mathrm{NaAlSi}_{3} \mathrm{O}_{8}$ melt- $\mathrm{H}_{2} \mathrm{O}$ : New calorimetric data and some geological implications, J. Geol., 95, 173-186, 1986.

Copeland, P., T.M. Harrison, and P. Le Fort, Age and cooling history of the Manaslu granite: Implications for Himalayan tectonics, J. Volcanol. Geotherm. Res., 44, 33-50, 1990.

Corry, C.E., Laccoliths: Mechanisms of emplacement and growth, Spec. Pap. Geol. Soc. Am., 220, 110 p., 1988.

Deniel, C., P. Vidal, A. Fernandez, P. Le Fort, and J.J. Peucat, Isotopic study of the Manaslu leucogranite (Himalaya, Nepal): Inferences on the age and source of Himalayan leucogranites, Contrib. Mineral. Petrol., 95, 78-92, 1987.

Emerman, S.H., and R. Marret, Why dikes?, Geology, 18, 231233, 1990.

England, P., P. Le Fort, P. Molnar, and A. Pêcher, Heat sources for Tertiary metamorphism and anatexis in the AnnapurnaManaslu region central Nepal, J. Geophys. Res., 97, 2107-2128, 1992.

France-Lanord, C., and P. Le Fort, Crustal melting and granite genesis during the Himalayan collision orogenesis, Trans. R. Soc. Edinburgh Earth Sci., 79, 183-195, 1988.

Guillot, S., P. Le Fort, A. Pêcher, M. Roy-Barman, and J. Aprahamian, Contact metamorphism and depth of emplacement of the Manaslu granite (central Nepal): Implications for Hirralayan orogenesis, Tectonophysics, 241, 99-119, 1993.

Harris, N.B.W., and S. Inger, Trace element modelling of pelite-derived granite:;, Contrib. Mineral. Petrol., 110, 46$56,1992$.
Hogan, J.P., and M.C. Gilbert, The A-type Mount Scott Granite Sheet: Importance of crustal magma traps, I. Geophys. Res., 100, 15,745-15,765, 1995.

Holtz, F., H. Behrens, D.B. Dingwell, and W. Johannes, $\mathrm{H}_{2} \mathrm{O}$ solubility in haplogranitic melts: Compositional, pressere and temperature dependence, Am. Mineral., 80, 94-108, 1995.

Inger, S., and N.B.W. Harris, Geochemical constraints leucogranite magmatism in the Langtang valley, Neped Himalaya, J. Petrol., 34, 345-368, 1993.

Jaupart, C., and C.J. Alègre, Gas content, eruption rate instabilities of eruption regime in silicic volcanoes, Earth Planet. Sci. Lett., 102, 413-429, 1991.

John, B.E., Structural reconstruction and zonation of a tilted mid-crustal magma chamber: The felsic Chemehveri Moutains plutonic suite, Geology, 16, 613-617, 1988.

Knoche, R., D.B. Dingwell, and S.L. Webb, Melt densities for leucogranites and granitic pegmatites: Partial molar volumes for $\mathrm{SiO}_{2}, \mathrm{Al}_{2} \mathrm{O}_{3}, \mathrm{Na}_{2} \mathrm{O}, \mathrm{K}_{2} \mathrm{O}, \mathrm{Li}_{2} \mathrm{O}, \mathrm{Rb}_{2} \mathrm{O}, \mathrm{Cr}_{2} \mathrm{O}$, $\mathrm{MgO}, \mathrm{CaO}, \mathrm{SrO}, \mathrm{BaO}, \mathrm{B}_{2} \mathrm{O}_{3}, \mathrm{P}_{2} \mathrm{O}_{5}, \mathrm{~F}_{2} \mathrm{O}_{-1}, \mathrm{TiO}_{2}, \mathrm{Nb}_{2} \mathrm{O}_{5}$, $\mathrm{Ta}_{2} \mathrm{O}_{5}$, and $\mathrm{WO}_{3}$, Geochim. Cosmochim. Acta, 59, 4645$4652,1995$.

Lange, R.A., and I.S.E. Carmichael, Thermodynamic properties of silicate liquids with emphasis on density, thermal expansion and compressibility, in Moders Methods in Igneous Petrology: Understanding Magmatic Processes, Rev. Mineral., vol. 24, edited by J. Nicholls and J.K. Russell, pp. 25-64, Mineral. Soc. of Am., Washington, D.C., 1990.

Lange, R.A., and A. Navrotsky, Heat capacities of $\mathrm{Fe}_{2} \mathrm{O}_{3}$ bearing silicate liquids, Contrib. Mineral. Petrol., 110, 311-320, 1992.

Laporte, D., Wetting behavior of partial melts during crustal anatexis: The distribution of hydrous silicic melts in polycrystalline aggregates of quartz, Contrib. Mineral. Perrol., 116, 486-499, 1994.

Le Fort P., Manaslu leucogranite: A collision signature of the Himalaya: A model for its genesis and emplacement, J. Geophys. Res., 86, 10545-10568, 1981.

Le Fort P., M. Cuney, C. Deniel, C. France-Lanord, S.M.F. Sheppard, B.N. Upreti, and P. Vidal, Crustal generation of Himalayan leucogranites, Tectonophysics, 134, 39-57, 1987.

Mahon, K. I., T.M. Harrison, and D.A. Drew, Ascent of a granitoid diapir in $a$ temperature varying medium, $J$. Geophy. Res., 93, 1174-1188, 1988.

McKenzie, D.P., The generation and compaction of partially molten rocks, J. Petrol., 25, 713-765, 1984.

Miller, C.F., E.B., Watson, and T.M. Harrison, Perspectives on the source, segregration and transport of granitoid magmas. Trans. R. Soc. Edinburgh Earth Sci., 79, 135-156. 1988.

Paterson, S.R., and T.K. Fowler, Re-examining plutom emplacement processes, J. Struct. Geol., 15, 191-206, 1993.

Paterson, S.R., R.H. Vernon, and T.K. Fowler, Aureole tectonics, in Contact Metamorphism, Rev. Mineral., vol. 26, edited by D.M. Kerrick, pp. 673-722, Mineral. Soc. of Am., Washington, D.C., 1991.

Pêcher, A., The metainorphism in central Himalaya, $J$. Metamorph. Geol., 7. 31-41, 1989.

Petford N., R.C., Kerr, and J.R. Lister, Dike transport of granitoid magmas, Geology, 21, 845-848, 1993.

Petford N., J.R. Lister, and R.C., Kerr, The ascent of felsie magmas in dykes, Lithos, 32, 161-168, 1994.

Pons, J., P. Barbey, D. Dupuis, and J.M. Léger, Mechanisan of pluton emplacement and structural evolution of $a 2.1 \mathrm{C}$ 
juvenile continental crust: The Birimian of southwestern Niger, Precambrian Res., 70, 281-302, 1995.

Roux, J., F. Holtz, A. Lefevre, and F. Schulze, A reliable hightemperature setup for internally heated pressure vessels: Applications to silicate melt studies Am. Mineral., 79, 1145-1149, 1994.

Rubin, A.M., Dikes vs. diapirs in viscoelastic rock, Earth Planet. Sci. Lett., 119, 641-659, 1993.

Rubin, A.M., Getting granite dikes out of the source region, J. Geophys. Res., 100, 5911-5929, 1995.

Scaillet, B., C. France Lanord, and P. Le Fort, BadrinathGangotri plutons (Garhwal, India): Petrological and geochemical evidence for fractionation processes in a High Himalayan leucogranite, J. Volcanol. Geotherm. Res., 44, 163-188, 1990.

Scaillet, B., A. Pêcher, P. Rochette, and M. Champenois, The Gangotri granite (Garhwal Himalaya): Laccolithic emplacement in an extending collisional belt, $J$. Geophys. Res., 100, 585-607, 1995a.

Scaillet, B., M. Pichavant, and J. Roux, Experimental crystallization of leucogranite magmas, J. Petrol., 36, 664706, 1995b.

Scaillet, B., F. Holtz, and M. Pichavant, Rheological properties of granitic magmas in their crystallization range, in Granite: From Segregation of Melt to Emplacement Fabrics, edited by J.L. Bouchez, D. Hutton, and W.S. Stephens, Kluwer Acad., Norwell, Mass., in press, 1996.
Schulze, F., H. Behrens, F. Holtz, J. Roux, and W. Johannes, The influence of water on the viscosity of a haplogranite liquid, Am. Mineral., in press, 1996.

Searle, M.P., R.P. Metcalfe, A.J. Rex, and M.N. Norry, Field relations, petrogenesis and emplacement of the Bhagirathi leucogranite, Garbwal Himalaya, in Himalayan Tectonics, edited by P.J. Treloar and M.P. Searle, Geol. Soc. Spec. Publ. London, 74, 429-444, 1993.

Shaw, H.R., Viscosities of magmatic silicate liquid: an empirical method of prediction: Am. J. Sci., 272, 870-893. 1972.

Wada, Y., On the relationship between dike width and magma viscosity, J.Geophys. Res., 99, 17743-17755, 1994.

Weinberg, R.F., and $Y$ Podladchikov, Diapiric ascent of magmas through power law crust and mantle, J.Geophys. Res., 99, 9543-9559, 1994.

Wickham, S.M., The segregation and emplacement of granitic magmas, J. Geol. Soc., 144, 281-297, 1987.

F. Holtz, M. Pichavant, ]3. Scaillet, and M. Schmidt, CRSCMCNRS, 1A rue de la Férollerie, 45071 Orléans Cedex 02,

France. (e-mail: bscaille @cnrs-orleans.fr)

(Received December 4, 1995; revised April 9, 1996;

accepted May 20, 1996.) 